\title{
SUBSTRATE STIFFNESS AFFECTS EARLY DIFFERENTIATION EVENTS IN EMBRYONIC STEM CELLS
}

\author{
Nicholas D. Evans ${ }^{1}$, Caterina Minelli ${ }^{1}$, Eileen Gentleman ${ }^{1}$, Vanessa LaPointe ${ }^{1}$, Sameer N. Patankar ${ }^{1,2}$, Maria \\ Kallivretaki ${ }^{1}$, Xinyong Chen $^{2}$, Clive J. Roberts ${ }^{2}$, Molly M. Stevens ${ }^{1 *}$ \\ ${ }^{1}$ Department of Materials and Institute of Biomedical Engineering, Imperial College London, London, U.K. \\ ${ }^{2}$ School of Pharmacy, University of Nottingham, Nottingham, U.K.
}

\begin{abstract}
Embryonic stem cells (ESC) are both a potential source of cells for tissue replacement therapies and an accessible tool to model early embryonic development. Chemical factors such as soluble growth factors and insoluble components of the extracellular matrix are known to affect the differentiation of murine ESCs. However, there is also evidence to suggest that undifferentiated cells can both sense the mechanical properties of their environment and differentiate accordingly. By growing ESCs on flexible polydimethylsiloxane substrates with varying stiffness, we tested the hypothesis that substrate stiffness can influence ESC differentiation. While cell attachment was unaffected by the stiffness of the growth substrate, cell spreading and cell growth were all increased as a function of substrate stiffness. Similarly, several genes expressed in the primitive streak during gastrulation and implicated in early mesendoderm differentiation, such as Brachyury, Mixl1 and Eomes, were upregulated in cell cultures on stiffer compared to softer substrates. Finally, we demonstrated that osteogenic differentiation of ESCs was enhanced on stiff substrates compared to soft substrates, illustrating that the mechanical environment can play a role in both early and terminal ESC differentiation. Our results suggest a fundamental role for mechanosensing in mammalian development and illustrate that the mechanical environment should be taken into consideration when engineering implantable scaffolds or when producing therapeutically relevant cell populations in vitro.
\end{abstract}

Keywords: Embryonic stem cells; cellular mechanotransduction; gastrulation; extracellular matrix; differentiation; mammalian development.

*Address for correspondence:

Molly Stevens

Dept Materials, Royal School of Mines,

Imperial College,

Prince Consort Road, London SW7 2BP, U.K.

E-mail: m.stevens@imperial.ac.uk
Introduction

Embryonic stem cells (ESCs) are pluripotent cells that can be isolated from the mammalian blastocyst and propagated in the laboratory indefinitely (Evans and Kaufman, 1981; Martin, 1981). These properties make them an exciting choice both as an accessible in vitro tool for studying the processes that control mammalian development and as a potential source of cells in regenerative medicine. Soluble growth factors - for example bone morphogenic proteins (Finley et al., 1999), activin (Sumi et al., 2008) and retinoic acid (Fraichard et al., 1995) - and insoluble proteins of the extracellular matrix (ECM) (Stevens and George, 2005; Takito and AlAwqati, 2004) influence cell fate in both the developing embryo and ESCs, and have been used in attempts to generate clinically relevant cell populations. However, during embryogenesis cells are exposed not only to chemical signals but also to physical forces. As groups of cells divide and make morphological movements necessary for the formation of new tissue, they both generate and experience tension, compression and shear forces (Keller et al., 2003). Cells sense these forces through cell-cell adhesion molecules, such as cadherins, and cell-matrix adhesion molecules, such as integrins, and respond accordingly (Wang et al., 2009). Recent work has demonstrated that physical compression alone is sufficient to activate Twist, a gene involved in gastrulation in Drosophila embryos (Farge, 2003; Desprat et al., 2008).

Well-documented cellular responses to applied mechanical forces, however, only reveal a single aspect of what we are beginning to understand to be a complex system of mechanical cell sensing. Mammalian cells not only sense applied mechanical forces, but also sense the mechanical properties of their environment, such as the elasticity of the substrate on which they grow. Substrate stiffness influences how strongly cells adhere, how much force they exert and their degree of spreading. (Yeung et al., 2005; Goffin et al., 2006; Pelham and Wang, 1997; Discher et al., 2005). Cells also proliferate more quickly on stiff compared to soft substrates (Peyton et al., 2006) and DNA synthesis proceeds more rapidly in flattened, well-spread cells (Folkman and Moscona, 1978). Furthermore, substrate stiffness also has a fundamental effect on cellular differentiation. Engler $e t$ al. showed that mesenchymal stem cells (MSCs) plated on soft substrates (with stiffnesses comparable to brain tissue) differentiated preferentially into neurons, while those plated on substrates with stiffness similar to muscle and bone tissue differentiated into myocytes and osteoblasts respectively 
(Engler et al., 2006). These effects may be related to the ability of a cell to spread on the substratum and form cytoskeletal stress fibres. MacBeath et al. have shown that MSCs prevented from spreading on small islands of ECM differentiate preferentially into adipocytes, while those allowed to spread on large islands differentiate readily to osteoblasts (McBeath et al., 2004). The effect of the mechanical environment on ESCs has been less well investigated, although there is evidence to suggest terminal differentiation in ESCs is affected by substrate compliance (Li et al., 2008). Earlier differentiation events remain uninvestigated.

In this study, we hypothesised that we could influence early differentiation events in ESCs by modulating substrate stiffness. We chose to pay particular attention to germ layer specification at gastrulation. Gastrulation is perhaps the first major morphological rearrangement of the early embryo and involves significant cell migration and tissue movement, and so we considered a role for cellular mechanosensing particularly important at this time. We synthesized substrates with varying stiffnesses using polydimethylsiloxane (PDMS), allowed ESCs to grow on them, and measured the expression of genes known to be involved in the process of gastrulation and germ layer formation. We also tested whether increasing stiffness of the substrate enhanced the terminal osteogenic differentiation of ESCs in the presence of osteogenic supplements.

\section{Materials and Methods}

\section{Material synthesis}

PDMS substrates of variable stiffnesses were fabricated using a SYLGARD 184 silicone elastomer kit (Dow Corning, Barry, UK) as per the manufacturer's instructions with crosslinker concentrations of 1, 3, 9, 17 and 23\% (w/ w). Mixed, degassed solutions were then poured into 6 well plates to a depth of at least $1 \mathrm{~mm}$ and cured at $70^{\circ} \mathrm{C}$ for 24 hours. Plates were rinsed in $70 \%$ ethanol, air dried and treated with ammonia plasma for 2 minutes at $50 \mathrm{~W}$ using a Plasma Prep 5 plasma machine (GaLa Gabler Labor Instrumente, Bad Schwalbach, Germany). Type I collagen was covalently linked to the PDMS surface using NSulfosuccinimidyl-6-(4'-azido-2'-nitrophenylamino) hexanoate (Sulpho-SANPAH; Thermo Fisher Scientific, Loughborough, UK) by the method of Pelham and Wang (Pelham and Wang, 1997). Sulfo-SANPAH was first dissolved in dimethyl sulfoxide (DMSO) at a concentration of $1 \mathrm{mg} / \mu \mathrm{l}$, and then diluted in $50 \mathrm{mM}$ HEPES (Sigma Aldrich, Dorset, U.K.), $\mathrm{pH} 8.5$, to a final concentration of $0.5 \mathrm{mg} / \mathrm{ml}$. Sulpho-SANPAH solution was used to cover the surface of each well in sterile conditions. Plates were then exposed to UV light from a transilluminator for 10 minutes from a distance of $10-30 \mathrm{~cm}$. Excess sulphoSANPAH solution was then removed and plates were subjected to a further 10 minutes exposure to UV light. Wells were then washed three times in sterile PBS and $1 \mathrm{ml}$ of a $50 \mu \mathrm{g} / \mathrm{ml}$ solution of type I collagen (BD
Biosciences, Oxford, U.K.) was added to each well. Wells were incubated at $4^{\circ} \mathrm{C}$ overnight. Collagen solution was then aspirated, each well was washed twice with sterile PBS and plates were stored at $4^{\circ} \mathrm{C}$ for up to 2 weeks.

\section{Substrate surface contact angle measurements}

Static water contact angle of the PDMS substrate surface was measured with an Easydrop Drop Shape Analysis System (Krüss Surface Science, Hamburg, Germany) before and after the collagen coating. A $5 \mu$ d drop of pure water was placed on the substrate surface and photographed. The shape of the drop was then analysed using a sessile drop fitting model. For each PDMS substrate, the measurements were performed on five different areas of the surface and the values were averaged.

\section{Substrate surface Young's modulus measurements}

The elastic properties of PDMS surfaces and mouse calvarium and liver (control adult tissues) were measured by atomic force microscopy (AFM). A PicoForce AFM with a NanoV controller (Veeco Instruments Inc., Cambridge, UK) was used for force measurement. A silicon probe (FESP type, also from Veeco) with cantilever spring constant of $4.5 \mathrm{~N} / \mathrm{m}$ for PDMS substrates, and $78 \mathrm{~N} / \mathrm{m}$ and $0.35 \mathrm{~N} / \mathrm{m}$ for calvarium and liver samples respectively, was modified by attachment of a $20.3 \pm 1.4 \mu \mathrm{m}$ diameter glass sphere (Borosilicate Glass Microspheres, Duke Scientific Co., Palo Alto, CA, USA) to the end of a cantilever with Loctite (Henkel, Düsseldorf, Germany) 350 UV adhesive. Force measurements on each PDMS sample were conducted as a $5 \times 5$ point matrix with an even separation of $10 \mu \mathrm{m}$. The Young's modulus, E, was calculated by averaging all 25 retracting force curves based on the Hertz model with the assumption that the glass sphere possesses an infinite $E$ in comparison to the sample surfaces.

\section{Cell culture and tissue isolation}

TG2 $\alpha$ E14 embryonic stem cells were grown in Dulbecco's modified Eagle's medium (DMEM) supplemented with 10\% (v/v) FBS, 2 mM L-glutamine (Invitrogen, Paisley, UK), $100 \mu \mathrm{M} \beta$-mercaptoethanol (Sigma, Dorset, UK) and $1000 \mathrm{U} / \mathrm{ml}$ leukaemia inhibitory factor (LIF), a growth factor used for the propagation of undifferentiated ESCs (Chemicon, Chandler's Ford, UK). Cells were fed every day and were passaged every 3-4 days at a density of 3000$6000 / \mathrm{cm}^{2}$. For differentiation experiments, undifferentiated ESCs were dissociated to single cells, and plated at a density of 30000 cells $/ \mathrm{cm}^{2}$ (unless stated otherwise) in alpha minimal essential medium ( $\alpha$ MEM) supplemented with $15 \%(\mathrm{v} / \mathrm{v})$ FBS without LIF. Cells were fed at day 2, then twice each day from day 3 to day 6 and once per day thereafter up to 10 days. Embryoid bodies (EBs) were made by partially dissociating ESCs to clumps containing around 15-30 cells and transferring them to non-adhesive bacteriagrade petri dishes. EBs were fed every 2 days.

Calvarium and liver samples were harvested from a 6week-old FVB/N female mouse, which was sacrificed in accordance with Imperial College London ethical guidelines. A scalpel blade was used to gently scrape away 
as much soft tissue as possible from the surface of harvested calvarium. Fresh liver and calvarium were frozen slowly in cell culture medium supplemented with FBS and DMSO. Samples were thawed at room temperature prior to testing.

\section{Adhesion and measurements of cell perimeter}

Cells were plated at 100000 cells/well, in 12-well plates. 24 hours post-plating cells were washed twice in PBS, fixed for 20 minutes with $70 \%(\mathrm{v} / \mathrm{v})$ ethanol, and then washed twice in PBS. Fixed cells were stained with $0.5 \%(\mathrm{w} / \mathrm{v})$ crystal violet for 10 minutes and dye was then extracted from cells with $0.1 \mathrm{M}$ citric acid. Absorbance was measured at $550 \mathrm{~nm}$ on an absorbance spectrometer (Anthos Labtec Instruments, Wals/Salzburg, Austria). Standard curves were created for known numbers of cells on fibronectin coated plates.

For measurements of cell perimeter, cultures of cells growing on each of the substrates were imaged and captured using an inverted phase contrast microscope (Olympus IX51, London, U.K.) equipped with DP Controller software. Three separate images of representative areas of each well were examined using ImageJ software (Freeware, available at http:// rsb.info.nih.gov/ij/) and single cells, identified by definite cell boundaries and single nuclei, were identified. Cell perimeter was measured by tracing the border of ten cells per image and measuring the border using the 'Perimeter' function of ImageJ.

\section{Cellular DNA quantification}

At indicated time-points ESCs were pelleted and incubated overnight with shaking at $56^{\circ} \mathrm{C}$ in $50 \mu \mathrm{g} / \mathrm{ml}$ Proteinase $\mathrm{K}$ solution (Sigma). After enzyme inactivation at $90^{\circ} \mathrm{C}$ for 10 minutes, Hoechst 33258 (Sigma) was added to a final concentration of $1 \mu \mathrm{g} / \mathrm{ml}$ and fluorescence emission was then measured at $450 \mathrm{~nm}$ under excitation at $350 \mathrm{~nm}$ on a fluorescence plate reader (MFX, Dynex Technologies, Chantilly, VA, USA). Aliquots containing known numbers of cells were pelleted and treated as above to obtain a standard curve for calculation of cell number from absorbance values. Measurements were performed in triplicate.

\section{Phalloidin staining of cells}

At 2 and 24 hours following seeding, ESCs were fixed for 20 minutes with $4 \%(\mathrm{w} / \mathrm{v})$ paraformaldehyde. Cells were then washed and incubated with $0.2 \%(\mathrm{v} / \mathrm{v})$ Triton X-100 (Sigma) for 45 minutes. Cells were washed twice in PBS and then incubated for 30 minutes in $0.1 \%(\mathrm{w} / \mathrm{v}) \mathrm{BSA}$. Cells were then covered with alexa-488-conjugated phalloidin (Invitrogen) at a concentration of $5 \mathrm{U} / \mathrm{ml}$ in PBS containing $0.1 \%(\mathrm{w} / \mathrm{v}) \mathrm{BSA}$ for 20 minutes according to the manufacturer's instructions. Cells were then washed twice in PBS and imaged with an upright fluorescence microscope (Olympus BX-60).

\section{Determination of cellular proteins using Western blot} Cells were seeded on substrates at 600000 cells $/ \mathrm{cm}^{2}$ in growth medium and were incubated for 2.5 hours. The cells were lysed for 10 minutes on ice in Radio
Immunoprecipitation Buffer (RIPA; Sigma) supplemented with phosphatase (Sigma) and protease (BD Biosciences) inhibitors. Lysates were centrifuged at $12000 \mathrm{~g}$ for 10 minutes and the soluble fraction was stored. $20 \mu \mathrm{g}$ total protein were separated in a $10 \%(\mathrm{w} / \mathrm{v}) \mathrm{SDS}$ polyacrylamide gel and electroblotted onto a polyvinylidiene difluoride membrane (Bio-Rad, Hertfordshire, UK). The membrane was blocked in 5\% $(\mathrm{w} / \mathrm{v}) \mathrm{BSA}$ for one hour at room temperature and then incubated in 1/1000 dilutions of primary antibodies (antifocal adhesion kinase (FAK) or anti-phosphorylated FAK (pFAK), Abcam, Cambridge, U.K.) overnight at $4^{\circ} \mathrm{C}$ with gentle agitation. The membranes were washed and then incubated in secondary antibodies conjugated with horseradish peroxidise (Bio-Rad) for 1 hour. Chemiluminescence substrate (Thermo Fisher Scientific, Loughborough, UK) was applied and protein was visualised with Syngene Dyversity CCD image analyse (Syngene, Cambridge, U.K.). Alpha-tubulin (Active Motif, Rixensart, Belgium) was used as a control at 1/5000 dilution. Western blot was repeated on three independent samples.

\section{Determination of cellular gene expression using quantitative PCR}

At indicated time-points, cultures of ESCs were pelleted and snap frozen in liquid nitrogen. RNA was isolated from cell pellets with an RNeasy kit (Qiagen, Hilden, Germany) according to the manufacturer's instructions. Sensimix OneStep kit (Quantace, London, U.K.) was used to perform reverse transcription and PCR on RNA in a single step, using SYBR green as a fluorescent dye to detect amplified double-stranded DNA. Thermal cycling and fluorescence detection was performed using a Corbett Rotorgene 6000 (Qiagen). Primers to Gapdh, Nanog, Fgf5, Brachyury, Foxa2, Sox1, Eomes, Mixl1, Twist1, Gata6, Cdh1, Cdh2, Runx2 and Spp1 were designed using Primer Bank (http:/ /pga.mgh.harvard.edu/primerbank/) and sequences and cycling conditions are listed in Supplementary Table 1. Serial 1:5 dilutions of isolated RNA were used to plot standard curves for each primer pair and therefore calculate efficiency. Quantification of gene expression was performed only in the linear range of each primer pair. The $\Delta \Delta C T$ method (Livak and Schmittgen, 2001) was used to quantify changes in the expression of each gene of interest between samples, using the housekeeping gene Gapdh as the normaliser.

\section{Osteogenic differentiation}

Undifferentiated ESCs were plated as described in 'Cell Culture' but were incubated in $\alpha$ MEM supplemented with $15 \%(\mathrm{v} / \mathrm{v})$ FBS, $280 \mu \mathrm{M}$ ascorbate, $10 \mathrm{mM} \beta$ glycerophosphate and $1 \mu \mathrm{M}$ dexamethasone (Sigma). Medium was changed every day up to day 6 and every 23 days thereafter for a period of 28 days. At day 28, cultures were fixed for 20 minutes in $10 \%$ (v/v) formalin buffered saline. Cells were then washed twice in PBS and $0.5 \mathrm{ml}$ $1 \%(\mathrm{w} / \mathrm{v})$ alizarin red $\mathrm{S}$ (Sigma), $\mathrm{pH} 4.2$ was added to each well for 10 minutes. Cultures were then washed thoroughly in running tap water until no further red stain 
was released from the cell layers, and were then left to air dry. Fixed cultures were then examined with an inverted fluorescence microscope (510-560 nm excitation, $>590$ $\mathrm{nm}$ emission). Representative images were taken and discrete, fluorescing areas were counted manually in each field of view.

To confirm the presence of calcium, differentiated cultures of ESCs were also stained for calcium using the von Kossa method. Briefly, cultures were washed in PBS, covered with a solution of $0.3 \mathrm{M} \mathrm{AgNO}_{3}$ and exposed to natural light for 1 hour. Cells were then washed twice in distilled water and covered with $0.33 \mathrm{M} \mathrm{Na}_{2} \mathrm{~S}_{2} \mathrm{O}_{3}$ for 5 minutes. Cultures were washed again and stained with nuclear fast red. Cultures were imaged under an inverted light microscope.

\section{Statistical analysis}

Results are expressed as mean \pm standard deviation. For each result, four separate, independent experiments were performed for each group unless otherwise stated $(n=4)$. All results were compared using a Student's $t$-test or oneway ANOVA with a post-hoc Tukey test. Pearson's correlation was used to test for significant linear relationships between substrate stiffness and gene expression. Significance was assumed when $p<0.05$.

\section{Results}

\section{Surface characterisation}

We created substrates suitable for cell culture with a range of stiffnesses using PDMS. Prior to surface treatment all PDMS surfaces were hydrophobic, with water droplet contact angles of around $120^{\circ}$. Following plasma treatment and covalent linkage of collagen to the surfaces, water droplet contact angle was reduced to $<90^{\circ}$ in all cases (Fig. 1A). There was no significant difference in contact angle between any of the surfaces, but contact angle was more variable on the softest PDMS substrate. Surfaces stored for up to 2 weeks did not show any change in hydrophilicity. There was no significant difference between the amount of collagen crosslinked onto each PDMS surface, but the amount of collagen on TCP was significantly higher $(p<0.05$; Supplementary Fig. 1). Indentation measurements of collagen-coated PDMS substrates by AFM yielded values of $0.041 \pm 0.005 ; 0.26$ $\pm 0.06 ; 1.86 \pm 0.14 ; 2.7 \pm 0.6$; and $2.33 \pm 0.15 \mathrm{MPa}$ for $1 \%, 3 \%, 9 \%, 17 \%$ and $23 \%$ concentrations of crosslinker respectively (Fig. 1B). All groups were significantly different from each other with $p<0.01$. Substrates will be referred to hereafter by their measured Young's moduli (0.041 MPa, 0.26 MPa, 1.9 MPa, 2.3 MPa and 2.7 MPa). Surface Young's moduli of calvaria and liver were measured at $0.15 \pm 0.04 \mathrm{MPa}$ and $0.018 \pm 0.015 \mathrm{MPa}$ respectively. Growth media incubated either with PDMS substrates or TCP contained less than $2 \mathrm{ppm} \mathrm{Si}$, as measured by ICP, indicating negligible leaching of elastomer or crosslinker into the growth medium (not shown).
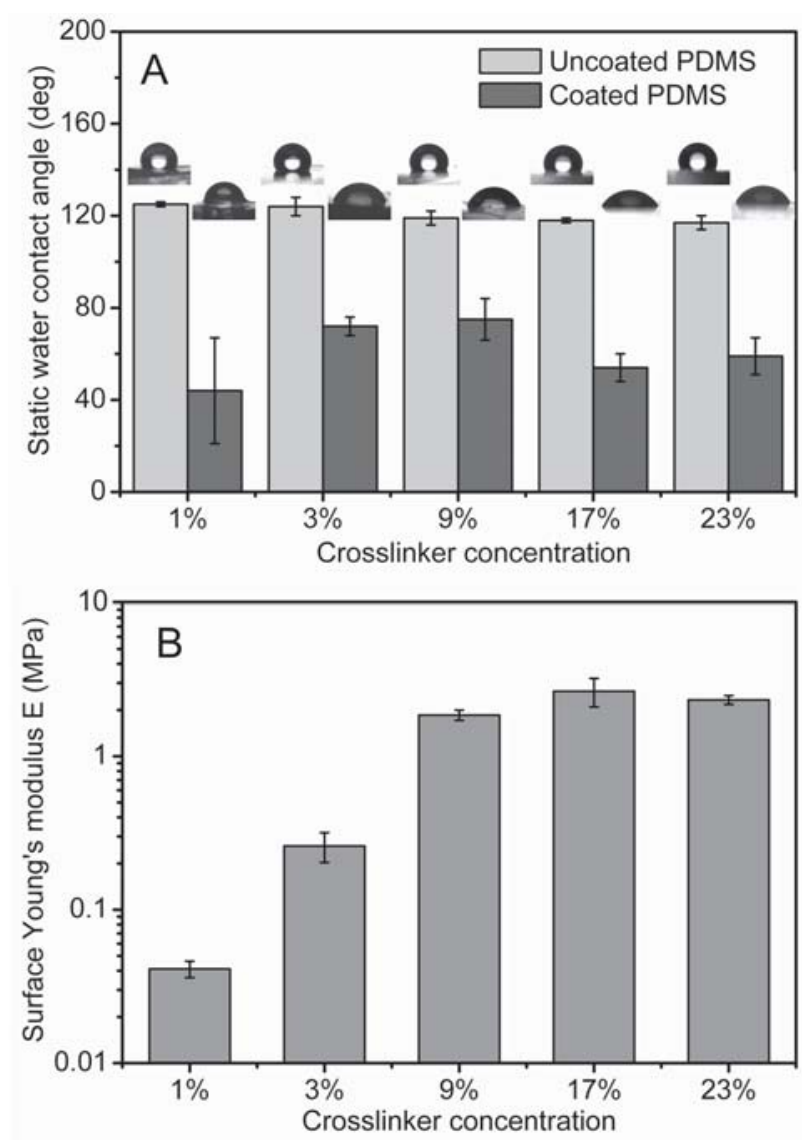

Figure 1. Surface characterization of PDMS substrates. (A) Covalent binding of type I collagen to PDMS substrates significantly increased surface wettability of all substrates, while there were no significant differences between substrates, as measured by static water contact angle. (B) Surface Young's moduli (E) measured using AFM demonstrated that 1\% PDMS < $3 \%<9 \%<23 \%<17 \%$ for $E$.

\section{Cell attachment and cell proliferation}

We next compared cell attachment and cell spreading on all surfaces using crystal violet and phalloidin staining, respectively. After 24 hours, cell attachment was greatest on the softest PDMS (0.041 MPa), although this was only significant compared to on 1.86 MPa PDMS ( $p=0.03$ ) (Fig. 2A). Cells exhibited similar morphology on all surfaces, with a mixture of stellate, rounded and bipolar morphologies (Fig. 2B). Quantitative measurements of cell perimeter showed no significant differences between the 3 stiffest substrates (1.9-2.7 MPa) and TCP. However, cell perimeter on the softest PDMS $(0.041 \mathrm{MPa})$ was significantly lower than on the second softest PDMS (0.26 $\mathrm{MPa}$ ). Furthermore, cell perimeter values on the two softest substrates were significantly lower than on all other surfaces $(p<0.01)$ (Fig. 2C).

Phalloidin staining of cytoskeletal actin after 2 hours showed plated cells had a poorly defined actin cytoskeleton on all substrates, with little evidence of stress fibre formation (Fig. 2D). Most staining was evident at the periphery of the cells. Cells appeared marginally more well spread on stiffer compared to soft substrates (Fig. 2D). At 24 hours, cytoskeletal stress fibres were more prominent 

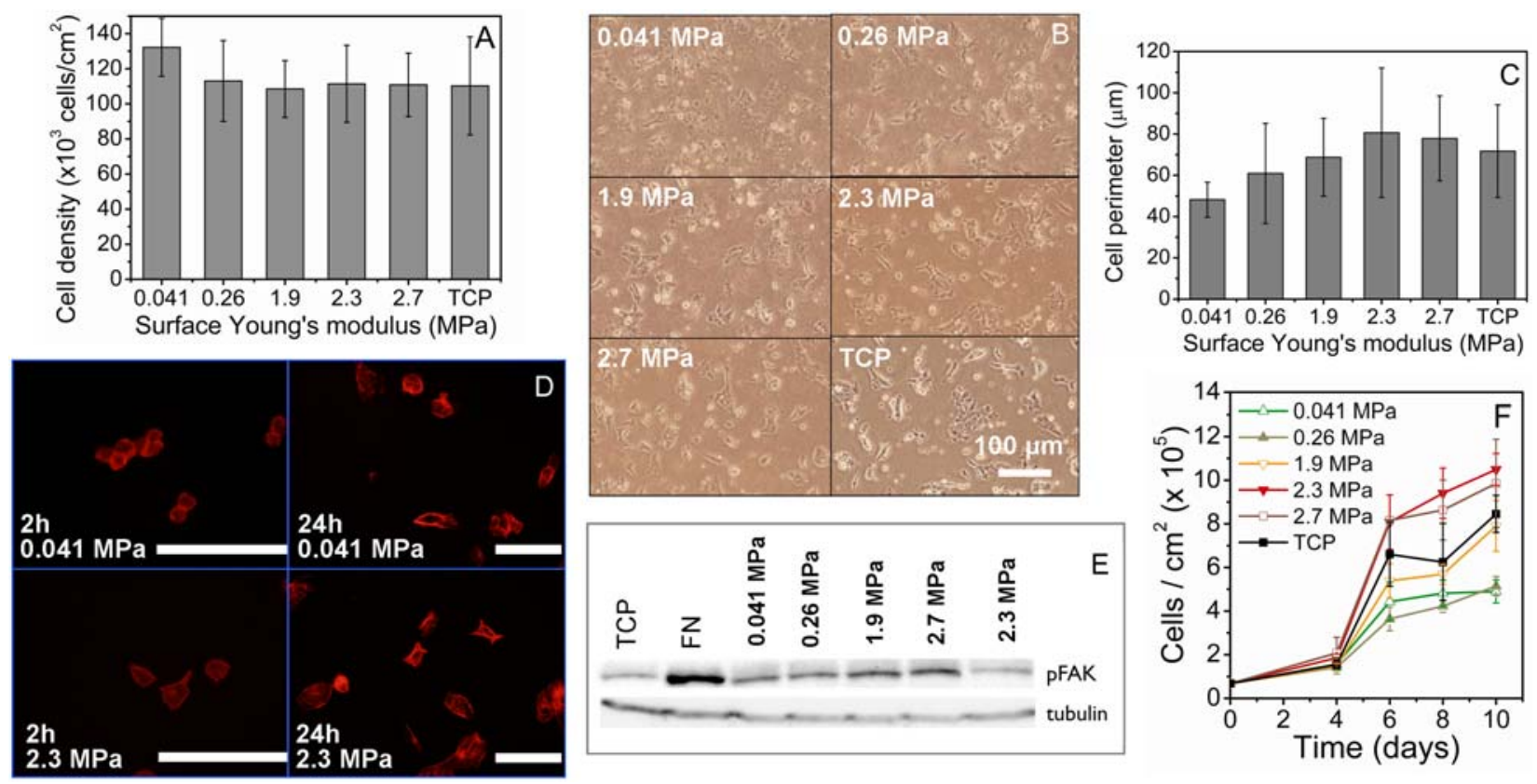

Figure 2. Effects of PDMS substrate stiffness on cell attachment and cell spreading. (A) Cell attachment measured after 24 hours in the presence of serum on PDMS substrates and TCP. Results are expressed as means of 3 experiments. Attachment was only significantly different between 0.041 MPa and 1.9 MPa PDMS $(p=0.03)$. (B) Phase contrast micrographs of cells on PDMS substrates and TCP after 24 hours. (C) Cell perimeter of cells adherent on PDMS and TCP surfaces after 24 hours. Results are representative of 3 experiments, with 10 single cells measured in 3 separate representative images. Cell perimeter on 0.041 MPa PDMS was significantly lower than on 0.26 MPa PDMS, and was lower on the two softest substrates than on any other substrate $(p<0.01)$. There were no significant differences between other substrates. (D) Phalloidin staining of intracellular actin (red) in cells cultured for 2 and 24 hours on 0.041 and 2.3 MPa PDMS substrates. White bars illustrate $100 \mu \mathrm{m}$. (E) Western blots for pFAK in lysates of cells adherent on PDMS substrates, fibronectin (FN) and TCP after 1 hour. $\alpha$-tubulin was also measured as a housekeeping control. (F) Total cell number per well in cultures of differentiating ESCs as a function of time was estimated by measurement of DNA concentration in protease-digested cell isolates.

on all surfaces, with the greatest visible formation of stress fibres on 2.3 MPa PDMS and TCP (Fig. 2D).

Measurement of pFAK by Western blot revealed that levels of this protein were similar on all PDMS substrates, but with slightly more protein detected in cells grown on substrates with Young's moduli of 1.9 and 2.7 MPa than in cells grown on substrates with Young's moduli of 0.04 , 0.26 and 2.3 MPa, or TCP (Fig. 2E). pFAK was highest on fibronectin, an ECM protein that promotes cell attachment. We next investigated whether there were any substratedependent differences in cell proliferation rates as measured by total DNA quantification. By day 4, there was no significant difference in cell number between any of the surfaces, but by day 6 there were significantly more cells on stiffer substrates $(1.9-2.7 \mathrm{MPa})$ than on soft substrates (0.041 and 0.26 MPa; $p<0.01$; Fig. $2 \mathrm{~F})$.

\section{Time course of gene expression}

We next investigated the time course of gene expression of several genes expressed in early mammalian development. As expected, the expression of Nanog (a marker of the inner cell mass and undifferentiated embryonic stem cells) decreased following withdrawal of LIF and remained low on all substrates. Expression levels did not differ significantly between substrates, but Nanog expression was significantly lower in EBs compared to on any substrate at day 8 and day $10(p<0.01)$ (Fig. 3A). The expression of Fgf5, a gene that is expressed in the primitive ectoderm of the developing mouse embryo but not in the inner cell mass or ESCs (Haub and Goldfarb, 1991) increased significantly by day 4, peaking at this time-point in cells on softer compared to stiffer PDMS substrates. Fgf5 expression in cells on PDMS substrates with Young's moduli of 2.3 and $2.7 \mathrm{MPa}$ and TCP was significantly higher than on other substrates and was sustained for a longer time period, with similar expression levels at day 8, before a decline. In EBs Fgf5 expression peaked at day 6 and was significantly higher at this time-point than in cells plated on any other substrate ( $p<0.01$; Fig. 3B). Expression of Brachyury, a gene involved in gastrulation and the formation of posterior mesoderm (Beddington et al., 1992; Wilson et al., 1995), peaked at day 6 in cells on all substrates and in EBs. Brachyury expression at this time point was lower on the softest PDMS than on any other substrate $(p<0.01)$ and increased in relation to substrate stiffness, with the highest expression on TCP. Brachyury expression however, was greatest in EBs, being a factor of 2.6 above that on TCP $(p<0.001$; Fig. $3 C)$. Expression of Foxa2, a marker expressed in the anterior primitive streak during gastrulation, and predominantly in definitive endoderm (Sasaki and Hogan, 1993), increased in cells on all substrates from before day 4 to day 10. Expression 

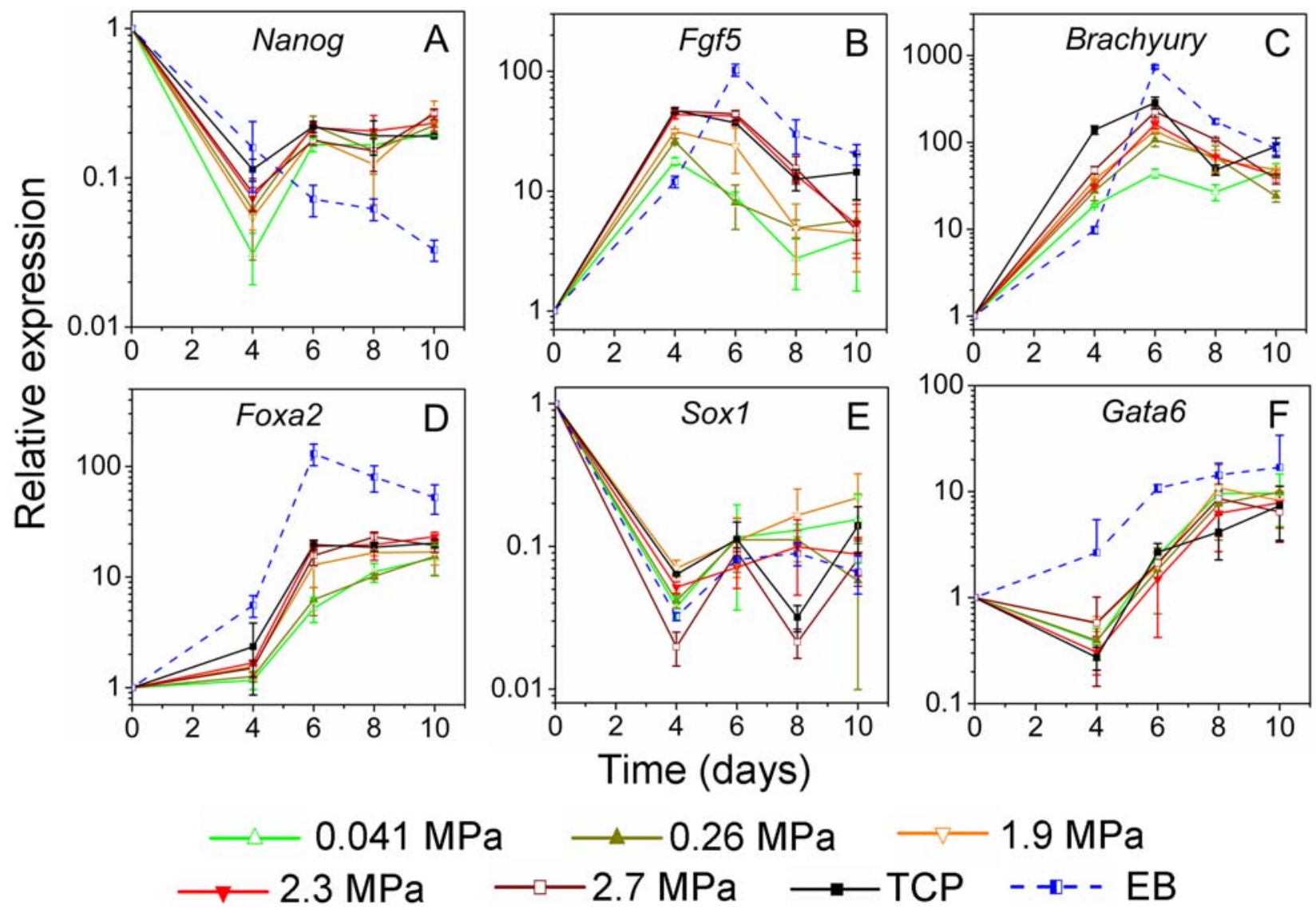

Figure 3. Time-course relative expression of genes involved in pluripotency (Nanog [A]), primitive ectoderm differentiation (Fgf5 [B]), posterior primitive streak and mesendoderm (Brachyury [C]), anterior primitive streak and mesendoderm (Foxa2 [D]), neuroepithelium (Sox1 [E]), and primitive endoderm (Gata6 [F]). Expression of all genes was normalised to the housekeeper, Gapdh, and results are expressed as relative increase compared to day 0 ESCs.

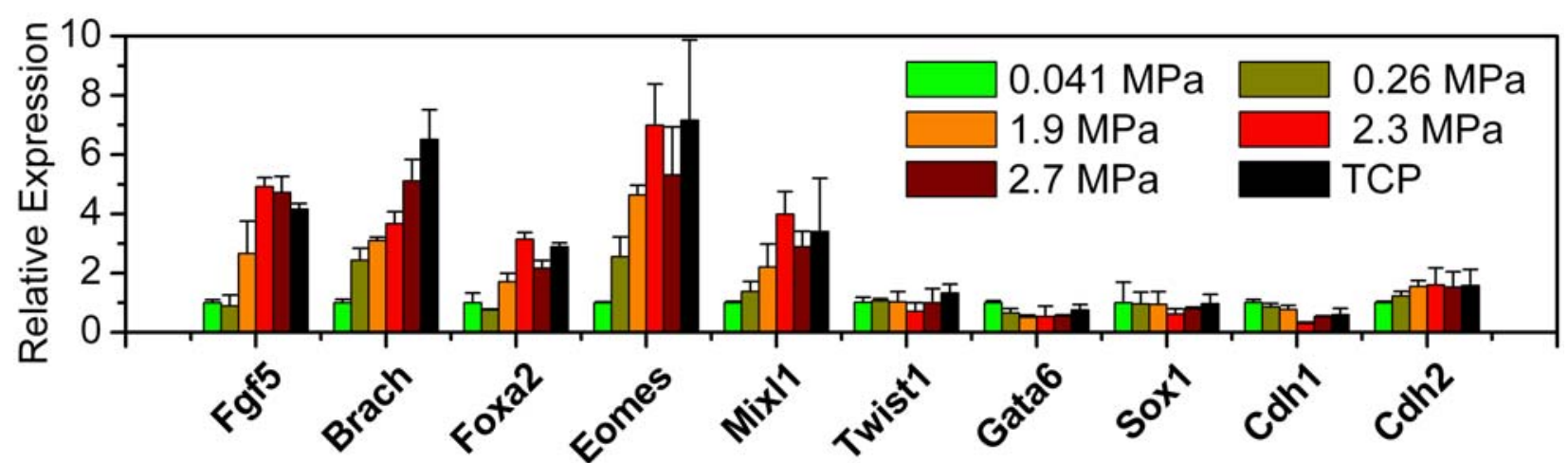

Figure 4. Relative expression of putative markers of the primitive ectoderm ( Fgf5), primitive streak and mesendoderm precursors (Brachyury, Foxa2, Eomes, Mixl1), anterior mesendoderm (Twist1), neuroepithelium (Sox1), primitive endoderm (Gata6) and cadherins 1 and 2 (E- and N-cadherin; Cdh1 and Cdh2) in cultures of ESCs 6 days after plating. Expression of all genes was normalised to the housekeeper, Gapdh, and results are expressed as relative increase compared to expression in cells on the softest PDMS at day 6.

of Foxa2 increased and peaked earlier in cells on stiffer substrates compared to those on softer substrates, with, like Brachyury, a progressive increase in expression with increasing substrate stiffness at day 6 ( $p<0.05$ between all groups except between cells on 2.7 MPa PDMS and TCP). In EBs Foxa2 expression was significantly higher than on any other substrate $(p<0.001$; Figure 3D). Expression of Sox1, a gene involved in the differentiation of neurectoderm from primitive ectoderm (Pevny et al.,
1998) declined significantly in all cells and did not differ significantly between cells on any substrate or in EBs (Fig. $3 \mathrm{E}$ ). Expression of Gata6, a gene involved in the differentiation of primitive endoderm and the extraembryonic tissues (Chazaud et al., 2006), initially decreased in cells on all substrates at day 4 , but then rose (Fig. 3F). There were no significant differences between substrates, but expression in EBs was significantly higher than on substrates at all other time points $(p<0.01)$. 


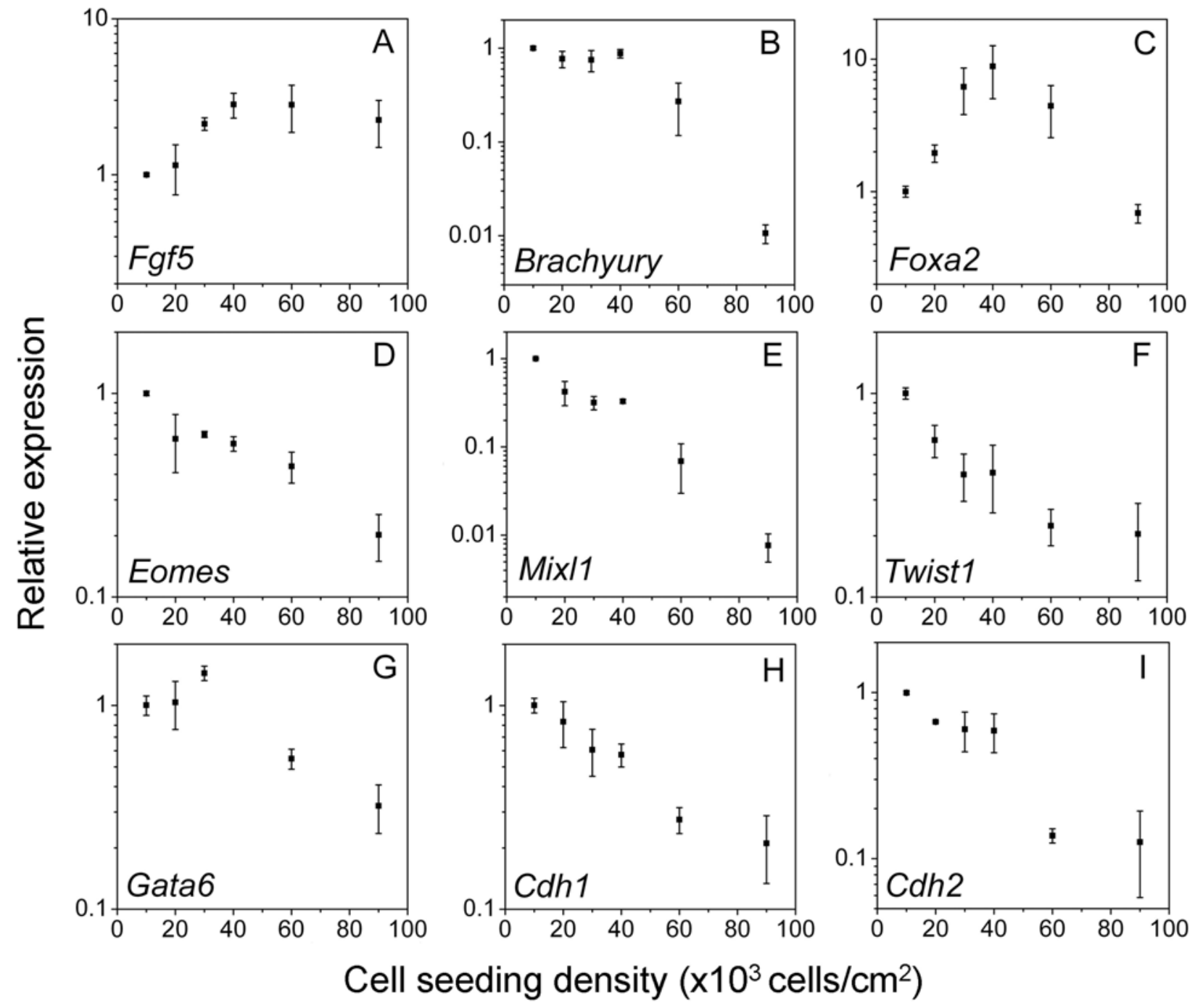

Figure 5. The effect of cell density on expression of putative markers of primitive ectoderm (Fgf5 [A]) the primitive streak and mesendoderm precursors (Brachyury [B], Foxa2 [C], Eomes [D], Mixl1 [E],), anterior mesendoderm (Twist1 [F]), primitive endoderm (Gata6 [G]) and cadherins 1 and 2 (E- and N-cadherin; Cdh1 [H] and Cdh2 [I]) in cultures of ESCs 6 days after plating. Expression of all genes was normalised to the housekeeper, Gapdh, and results are expressed as relative increase compared to expression in cells 6 days after plating at a density of $10000 \mathrm{cells} / \mathrm{cm}^{2}$.

\section{Expression of markers of primitive streak at day 6} Because of the substrate-dependent differences in expression of Brachyury and Foxa2, we next investigated whether there were relationships between the expression of other genes expressed in the primitive streak and in progenitors of the mesoendoderm. Both Mixl1 and Eomes are expressed in the primitive streak during gastrulation (the latter gene is also expressed in the trophectoderm and extraembryonic ectoderm; Hart et al., 2002; Pearce and Evans, 1999; Ciruna and Rossant, 2001; Tam et al., 2007; Arnold et al., 2008) and have putative roles in mesendoderm differentiation and patterning. Expression of Brachyury, Foxa2, Mixl1 and Eomes were positively correlated with substrate stiffness when analysed by Pearson's correlation ( $p<0.001$; Fig. 4). Twist1, which in Drosophila is necessary for gastrulation but which in mammals is expressed in anterior and lateral tissues and not in the primitive streak (Fuchtbauer, 1995), showed no significant correlation with substrate stiffness $(p=0.36)$.
Gata6, a marker of primitive endoderm, and Sox1, a neuroepithelial marker, where both negatively correlated with substrate stiffness ( $p<0.001)$. Cdh1 (E-cadherin), a gene which is expressed in primitive ectoderm but which is downregulated in cells migrating though the primitive steak, was negatively correlated with substrate stiffness ( $p<0.001$; Fig. 4), while in contrast Cdh2 (N-cadherin), which is expressed in the nervous system and in mesoderm cells during gastrulation (Winklbauer et al., 1992; Yang et al., 2008), was positively correlated with substrate stiffness $(p=0.003)$.

\section{The effect of cell density on gene expression}

We next investigated whether the increased cell density (associated with increased growth on stiffer substrates) could be the cause of the relationships between gene expression and substrate stiffness. We seeded ESCs at various cell densities and measured gene expression at day 6. Brachyury, Mixl1, Eomes, Twist1, Cdh1 and Cdh2 were 

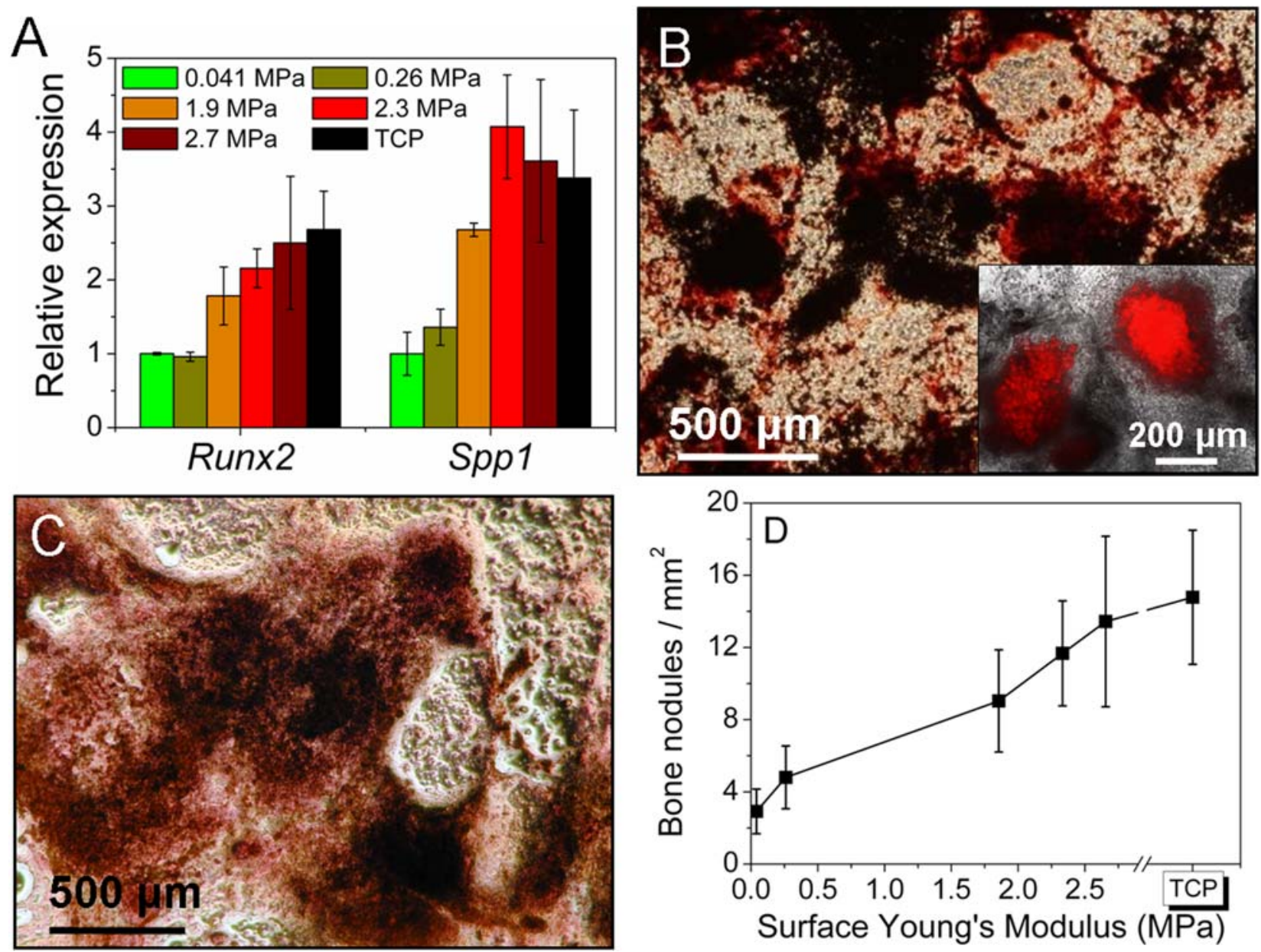

Figure 6. Osteogenic differentiation of ESCs grown on PDMS substrates and TCP for 28 days in the presence of osteogenic supplements. (A) Both Runx2 and Spp1 (osteopontin gene) are upregulated on stiffer compared to softer substrates in cultures of ESCs 16 days after plating. Expression of genes was normalised to Gapdh and is expressed relative to expression on 0.041 MPa PDMS. (B) Mineralised areas sequester alizarin red S and fluoresce at wavelengths of >590 nm under excitation at 510-560 nm (inset) or (C) sequester $\mathrm{Ag}^{2+}$ when stained using Von Kossa's method. (D) 28 days after plating, ESC cultures grown in osteogenic supplements were fixed, stained with alizarin red S, and mineralised areas were manually counted as discrete fluorescing areas. The number of mineralised areas increased in relation to substrate stiffness.

all negatively regulated by increasing cell density. Foxa2 and Gata6 showed a biphasic pattern of gene expression, with the greatest expression levels in cultures seeded at 40000 cells $/ \mathrm{cm}^{2}$ while $F g f 5$ expression was upregulated at higher cell densities (Fig. 5A-G).

\section{Osteogenic differentiation on PDMS substrates}

We finally investigated whether substrate stiffness affected the terminal differentiation of ESCs by culturing them in the presence of supplements known to induce osteogenic differentiation (Gentleman et al., 2009; Buttery et al., 2001). At day 11, we found significant upregulation of both Runx2 and Spp1 (osteopontin) on stiff compared to soft substrates with a significant positive correlation between gene expression and substrate stiffness $(p<0.001$; Fig. 6A). On all substrates, ESCs formed mineralised deposits containing $\mathrm{Ca}^{2+}$ salts that sequestered either alizarin red $\mathrm{S}$, or $\mathrm{Ag}^{2+}$ using von Kossa's method, suggesting the formation of mineralised bone-like tissue
(Fig. 6B and 6C). The amount of alizarin red S staining was positively correlated with the stiffness of the substrate on which the cells were plated ( $p<0.001$; Fig. 6D).

\section{Discussion}

We have demonstrated here that substrate stiffness affects cell spreading, growth rate, gene expression and osteogenic differentiation of ESCs. While cell attachment was unaffected by the stiffness of the growth substrate, cell spreading and cell proliferation were increased as a function of substrate stiffness. Similarly, several genes expressed in the primitive streak during gastrulation, and implicated in early mesendoderm differentiation, were upregulated in cell cultures as substrate stiffness increased from $41 \mathrm{kPa}$ to $2.7 \mathrm{MPa}$. This effect was not dependent on cell density, and suggests that increasing stiffness of the substrate promotes mesendoderm differentiation. Finally, 
we demonstrated that osteogenic differentiation of ESCs was enhanced as substrate stiffness increased illustrating the importance of mechanical environment in both early and terminal ESC differentiation.

We chose PDMS as a substrate because it is easy to prepare, transparent, non-toxic, and flexible, and does not either dissolve or swell in cell culture medium. We were able to fabricate reproducibly substrates ranging in stiffness from $41 \mathrm{kPa}$ to $2.7 \mathrm{MPa}$ (in a similar range to those previously reported (Tzvetkova-Chevolleau et al., 2008; Goffin et al., 2006; Cheng et al., 2009; Brown et al., $2005))$. At high crosslinker concentrations $(23 \%$ [w/w]) we noted a decrease in substrate stiffness, which can be attributed to the presence of unbound, mobile crosslinker molecules (Lee et al., 2004). Surface elastic moduli reported for adult tissue range from $17 \mathrm{~Pa}$ for fat to $>1$ GPa for bone (Levental et al., 2007; Hengsberger et al., 2002; Mankani et al., 2006), although most tissues have elastic moduli less than $0.2 \mathrm{MPa}$. Here we used AFM to determine the surface Young's moduli of liver and calvarial bone and found these to be $0.018 \mathrm{MPa}$ and $0.150 \mathrm{MPa}$ respectively. The modulus we measured for calvarial bone was several orders of magnitude lower than found in another recent study (Balooch et al., 2005), although this may be explained by differences in sample preparation: our AFM measurements were conducted on the surfaces of the fresh calvarium in wet conditions, whereas Balooch et al. conducted experiments on epoxy-embedded bone cross-sections in dry conditions. There is a paucity of data available for embryonic tissues, but $E$ has been measured at around $1 \mathrm{kPa}$ in the blastula wall of sea urchin (Strongylocentrotus purpuratus) embryos (von Dassow and Davidson, 2007). We suspect that the elastic moduli of substrates fabricated in the current study are higher than those that exist in the early embryo. However, attempts to fabricate substrates with lower elastic moduli by using crosslinker concentrations of $<1 \%$ were unsuccessful substrates were difficult to handle and never solidified. Future studies may use polyacrylamide (PA) gels, which range in $E$ from $<1 \mathrm{kPa}-100 \mathrm{kPa}$ (Engler et al., 2006; Khatiwala et al., 2007; Pelham, Jr. and Wang, 1997), to probe the effect of softer substrates on ESC differentiation.

Despite the relatively high elastic moduli of substrates in our experiments we were able to distinguish substratedependent biological effects. Both proliferation and cell spreading were significantly greater with increasing stiffness of the substrate, in agreement with several other studies (Rowlands et al., 2008; Khatiwala et al., 2006; Folkman and Moscona, 1978; Peyton et al., 2006; Yeung et al., 2005). We also measured an upregulation of genes expressed in the primitive streak and nascent mesendoderm - Foxa2, Brachyury, Mixl1, Cdh2, and Eomes - and a subsequent stimulation of osteogenic differentiation (a tissue derived in large part from the mesoderm) with increasing stiffness of substrates. We consider it unlikely that these effects are due to the chemical composition of the substrates as ICP analysis of cell culture medium revealed that the elemental $\mathrm{Si}$ (present in all components of PDMS) content remained below $2 \mathrm{ppm}$ on all substrates, including tissue culture plastic - a value similar to the trace amount found in blood plasma (Bercowy et al., 1994).
Instead, our results suggest either a direct effect of the mechanical properties of the substrates on cell differentiation, or an indirect effect related to the increased cell proliferation and cell density measured on stiffer substrates; for example by paracrine growth-factor signalling, nutrient depletion, or direct cell-cell contact, rather than by substrate stiffness per se (Dietrich et al., 2002). But in direct contradiction to the latter hypothesis we found that Brachyury, Mixl1, Cdh2 and Eomes were all down-regulated by increasing cell density in control experiments (Fig. 5). We therefore consider it likely that substrate stiffness directly stimulates the growth and differentiation of mesendoderm cells.

The mechanism underlying these observations may be related to the increased cell spreading that we observed with increasing substrate stiffness. Burdsal et al. demonstrated that cells derived from epiblast tissue (dissected from murine embryos) could be induced to flatten in culture and to differentiate to cells with the characteristics of mesoderm by incubating them with function-perturbing antibodies against E-cadherin (which inhibit cell-cell adhesion and stimulate cell-ECM adhesion) (Burdsal et al., 1993). Indeed, it is established that cells that undergo gastrulation lose their tightly packed epithelial morphology, and assume a stellate, migratory mesenchymal morphology (Baum et al., 2008; Tam et al., 1993). This epithelial to mesenchymal transition (EMT) allows these cells to actively adhere to and migrate through the ECM-rich space between the epiblast and the visceral endoderm, eventually forming the endodermal and mesodermal tissues of the adult organism. The importance of this process is revealed in embryos which lack gastrulation-related genes - Brachyury, Eomes and Mixl1 mutants all have defects in mesendoderm patterning with an associated accumulation of cells at the primitive streak during gastrulation (Arnold et al., 2008; Tam et al., 2007; Wilson et al., 1995). This defect suggests that the accumulated cells are unable to migrate properly and pattern the mesendoderm, a finding that is also supported by in vitro observations of the impaired migration of mesodermal cells from Brachyury mutants (Hashimoto et al., 1987) (but not in Eomes mutants (Arnold et al., 2008)). These results suggest that one function of these genes may be to regulate the expression of cell attachment molecules involved in cell migration and cell-ECM attachment during gastrulation (Smith, 1997; Wilson et al., 1995). Thus in our experiments, stiffer substrates may support the growth and differentiation of more adhesive cells expressing these genes that arise in cultures of differentiating ESCs by providing an environment that more closely mimics the environment migrating mesendoderm cells experience in the early embryo. We did not directly test whether or not increased contractility in uncommitted cells on stiffer substrates stimulates differentiation directly. Future studies may seek to address this by examining the effect of inhibitors of cellular contractility on differentiation, or by immunostaining cells plated at low density on substrates of differing stiffnesses (Engler et al., 2006).

We also noted in our experiments that Twist1 expression was unaffected by substrate stiffness. Unlike in Drosophila where its homologue has been shown to be 
mechanosensitive, Twist 1 is not expressed in the primitive streak or in the regions surrounding it in the mouse but instead is expressed subsequently by cells that have migrated to the anterior part of the embryo (Fuchtbauer, 1995). Thus it is possible that the time-point we investigated (day 6) was too early to detect substratedependent changes in the expression of this gene. We also noted that the expression of Foxa 2 and Brachyury - genes that we found to be influenced by substrate stiffness - were expressed at much higher levels in EBs (where there is no substrate) than on either PDMS substrates or TCP. This is likely to be due to the three-dimensional nature of EBs, where cells are permitted to undergo similar morphological arrangements to those in the early embryo, a situation which is prevented in $2 \mathrm{D}$ cell culture and which in $3 \mathrm{D}$ culture is known to accentuate early cell differentiation events in ESCs (Levenberg et al., 2003; Levenberg et al., 2005)

\section{Conclusions}

In this study we conclude that increasing substrate stiffness from $0.041 \mathrm{MPa}$ to $2.7 \mathrm{MPa}$ promotes cell spreading, cell proliferation, mesendodermal gene expression and terminal osteogenic differentiation of ESCs. As well as illustrating that the mechanical environment is an important factor in cellular differentiation in the developing embryo, these results suggest that the growth substratum should be carefully considered in any attempts to grow and differentiate relevant cell populations in vitro for clinical applications.

\section{Acknowledgements}

NDE was funded by a collaborative career development fellowship from the Medical Research Council, UK. CM was partially funded by the European Community's Seventh Framework Programme under grant agreement PIEF-GA-2008-219573. MMS thanks the Engineering and Physical Sciences Research Council (UK) for funding.

\section{References}

Arnold SJ, Hofmann UK, Bikoff EK, Robertson EJ (2008) Pivotal roles for eomesodermin during axis formation, epithelium-to-mesenchyme transition and endoderm specification in the mouse. Development 135: 501-511.

Balooch G, Balooch M, Nalla RK, Schilling S, Filvaroff EH, Marshall GW, Marshall SJ, Ritchie RO, Derynck R, AllistonT (2005) TGF-beta regulates the mechanical properties and composition of bone matrix. Proc Natl Acad Sci USA 102; 18813-18818.

Baum B, Settleman J, Quinlan MP (2008) Transitions between epithelial and mesenchymal states in development and disease. Semin Cell Dev Biol 19: 294-308.

Beddington RS, Rashbass P, WilsonV (1992) Brachyury - a gene affecting mouse gastrulation and early organogenesis. Dev Suppl 157-165.
Bercowy GM, Vo H, Rieders F (1994) Silicon analysis in biological specimens by direct current plasma-atomic emission spectroscopy. J Anal Toxicol 18: 46-48.

Brown XQ, Ookawa K, Wong JY (2005) Evaluation of polydimethylsiloxane scaffolds with physiologicallyrelevant elastic moduli: interplay of substrate mechanics and surface chemistry effects on vascular smooth muscle cell response. Biomaterials 26: 3123-3129.

Burdsal CA, Damsky CH, Pedersen RA (1993) The role of E-cadherin and integrins in mesoderm differentiation and migration at the mammalian primitive streak. Development 118: 829-844.

Buttery LD, Bourne S, Xynos JD, Wood H, Hughes FJ, Hughes SP, Episkopou V, Polak JM (2001). Differentiation of osteoblasts and in vitro bone formation from murine embryonic stem cells. Tissue Eng 7: 89-99.

Chazaud C, Yamanaka Y, Pawson T, Rossant J (2006) Early lineage segregation between epiblast and primitive endoderm in mouse blastocysts through the Grb2-MAPK pathway. Dev. Cell 10: 615-624.

Cheng CM, Steward RL Jr, Leduc PR (2009) Probing cell structure by controlling the mechanical environment with cell-substrate interactions. J Biomech 42: 187-192.

Ciruna B, Rossant J (2001) FGF signaling regulates mesoderm cell fate specification and morphogenetic movement at the primitive streak. Dev Cell 1: 37-49.

Desprat N, Supatto W, Pouille PA, Beaurepaire E, Farge E (2008) Tissue deformation modulates twist expression to determine anterior midgut differentiation in Drosophila embryos. Dev Cell 15: 470-477.

Dietrich C, Scherwat J, Faust D, Oesch F (2002) Subcellular localization of beta-catenin is regulated by cell density. Biochem Biophys Res Commun 292: 195-199.

Discher DE, Janmey P, WangYL (2005) Tissue cells feel and respond to the stiffness of their substrate. Science 310: 1139-1143.

Engler AJ, Sen S, Sweeney HL, Discher DE (2006) Matrix elasticity directs stem cell lineage specification. Cell 126: 677-689.

Evans MJ, Kaufman MH (1981) Establishment in culture of pluripotential cells from mouse embryos. Nature 292: 154-156.

Farge E (2003) Mechanical induction of Twist in the Drosophila foregut/stomodeal primordium. Curr Biol 13: 1365-1377.

Finley MF, Devata S, Huettner JE (1999) BMP-4 inhibits neural differentiation of murine embryonic stem cells. J Neurobiol 40: 271-287.

Folkman J, Moscona A (1978) Role of cell shape in growth control. Nature 273: 345-349.

Fraichard A, Chassande O, Bilbaut G, Dehay C, Savatier P, Samarut J (1995) In vitro differentiation of embryonic stem cells into glial cells and functional neurons. J Cell Sci 108: 3181-3188.

Fuchtbauer EM (1995) Expression of M-twist during postimplantation development of the mouse. Dev Dyn 204: 316-322.

Gentleman E, Swain RJ, Evans ND, Boonrungsiman S, Jell G, Ball MD, Shean TA, Oyen ML, PorterA, Stevens MM (2009) Comparative materials differences revealed 
in engineered bone as a function of cell-specific differentiation. Nat Mater 8: 763-770.

Goffin JM, Pittet P, Csucs G, Lussi JW, Meister JJ, Hinz B (2006) Focal adhesion size controls tension-dependent recruitment of alpha-smooth muscle actin to stress fibers. J Cell Biol 172: 259-268.

Hart AH, Hartley L, Sourris K, Stadler ES, Li R, Stanley EG, Tam PP, Elefanty AG, Robb L (2002) Mixl1 is required for axial mesendoderm morphogenesis and patterning in the murine embryo. Development 129: 3597-3608.

Hashimoto K, Fujimoto H, Nakatsuji N (1987) An ECM substratum allows mouse mesodermal cells isolated from the primitive streak to exhibit motility similar to that inside the embryo and reveals a deficiency in the $\mathrm{T} / \mathrm{T}$ mutant cells. Development 100: 587-598.

Haub O, Goldfarb M (1991) Expression of the fibroblast growth factor-5 gene in the mouse embryo. Development 112: 397-406.

Hengsberger S, Kulik A, Zysset P (2002) Nanoindentation discriminates the elastic properties of individual human bone lamellae under dry and physiological conditions. Bone 30: 178-184.

Keller R, Davidson LA, Shook DR (2003) How we are shaped: the biomechanics of gastrulation. Differentiation 71: 171-205.

Khatiwala CB, Peyton SR, Metzke M, Putnam AJ (2007) The regulation of osteogenesis by ECM rigidity in MC3T3-E1 cells requires MAPK activation. J Cell Physiol 211: 661-672.

Khatiwala CB, Peyton SR, Putnam AJ (2006) Intrinsic mechanical properties of the extracellular matrix affect the behavior of pre-osteoblastic MC3T3-E1 cells. Am J Physiol Cell Physiol 290: C1640-C1650.

Lee JN, Jiang X, Ryan D, Whitesides GM (2004) Compatibility of mammalian cells on surfaces of poly(dimethylsiloxane). Langmuir 20: 11684-11691.

Levenberg S, Burdick JA, Kraehenbuehl T, Langer R (2005) Neurotrophin-induced differentiation of human embryonic stem cells on three-dimensional polymeric scaffolds. Tissue Eng 11: 506-512.

Levenberg S, Huang NF, Lavik E, Rogers AB, Itskovitz-Eldor J, Langer R (2003) Differentiation of human embryonic stem cells on three-dimensional polymer scaffolds. Proc Natl Acad Sci USA 100: 12741-12746.

Levental I, Georges PC, Janmey PA (2007) Soft biological materials and their impact on cell function. Soft Matter 3: 299-306.

Li L, Sharma N, Chippada U, Jiang X, Schloss R, Yarmush ML, Langrana NA (2008) Functional modulation of ES-derived hepatocyte lineage cells via substrate compliance alteration. Ann Biomed Eng 36: 865-876.

Livak KJ, Schmittgen TD (2001) Analysis of relative gene expression data using real-time quantitative PCR and the 2(-Delta Delta C(T)) Method Methods 25: 402-408.

Mankani MH, Kuznetsov SA, Wolfe RM, Marshall GW, Robey PG (2006) In vivo bone formation by human bone marrow stromal cells: reconstruction of the mouse calvarium and mandible. Stem Cells 24: 2140-2149.

Martin GR (1981) Isolation of a pluripotent cell line from early mouse embryos cultured in medium conditioned by teratocarcinoma stem cells. Proc Natl Acad Sci USA 78: 7634-7638.

McBeath R, Pirone DM, Nelson CM, Bhadriraju K, Chen CS (2004) Cell shape, cytoskeletal tension, and RhoA regulate stem cell lineage commitment. Dev Cell 6: 483495.

Pearce JJ, Evans MJ (1999) Mml, a mouse Mix-like gene expressed in the primitive streak. Mech Dev 87: 189192.

Pelham RJ Jr, Wang Y (1997) Cell locomotion and focal adhesions are regulated by substrate flexibility. Proc Natl Acad Sci USA 94: 13661-13665.

Pevny LH, Sockanathan S, Placzek M, Lovell-Badge $\mathrm{R}$ (1998) A role for SOX1 in neural determination. Development 125: 1967-1978.

Peyton SR, Raub CB, Keschrumrus VP, Putnam AJ (2006) The use of poly(ethylene glycol) hydrogels to investigate the impact of ECM chemistry and mechanics on smooth muscle cells. Biomaterials 27: 4881-4893.

Rowlands AS, George PA, Cooper-White JJ (2008) Directing osteogenic and myogenic differentiation of MSCs: interplay of stiffness and adhesive ligand presentation. Am J. Physiol Cell Physiol 295: C1037C1044.

Sasaki H, Hogan BL (1993) Differential expression of multiple fork head related genes during gastrulation and axial pattern formation in the mouse embryo. Development 118: $47-59$.

Smith J (1997) Brachyury and the T-box genes. Curr Opin Genet Dev 7: 474-480.

Stevens MM, George JH (2005) Exploring and engineering the cell surface interface. Science 310: 11351138.

Sumi T, Tsuneyoshi N, Nakatsuji N, Suemori H (2008) Defining early lineage specification of human embryonic stem cells by the orchestrated balance of canonical Wnt/ beta-catenin, Activin/Nodal and BMP signaling. Development 135: 2969-2979.

Takito J, Al-Awqati Q (2004) Conversion of ES cells to columnar epithelia by hensin and to squamous epithelia by laminin. J Cell Biol 166: 1093-1102.

Tam PP, Williams EA, Chan WY (1993) Gastrulation in the mouse embryo: ultrastructural and molecular aspects of germ layer morphogenesis. Microsc Res Tech 26: 301328 .

Tam PP, Khoo PL, Lewis SL, Bildsoe H, Wong N, Tsang TE, Gad JM, Robb L (2007) Sequential allocation and global pattern of movement of the definitive endoderm in the mouse embryo during gastrulation. Development 134: 251-260.

Tzvetkova-Chevolleau T, Stephanou A, Fuard D, Ohayon J, Schiavone P, Tracqui P (2008) The motility of normal and cancer cells in response to the combined influence of the substrate rigidity and anisotropic microstructure. Biomaterials 29: 1541-1551.

Von Dassow M, Davidson LA (2007) Variation and robustness of the mechanics of gastrulation: the role of tissue mechanical properties during morphogenesis. Birth Defects Res C Embryo Today 81: 253-269. 
Wang N, Tytell JD, Ingber DE (2009) Mechanotransduction at a distance: mechanically coupling the extracellular matrix with the nucleus. Nat Rev Mol Cell Biol 10: 75-82.

Wilson V, Manson L, Skarnes WC, Beddington RS (1995) The T gene is necessary for normal mesodermal morphogenetic cell movements during gastrulation. Development 121: 877-886.

Winklbauer R, Selchow A, Nagel M, Angres B (1992) Cell interaction and its role in mesoderm cell migration during Xenopus gastrulation. Dev Dyn 195: 290-302.
Yang X, Chrisman H, Weijer CJ (2008) PDGF signalling controls the migration of mesoderm cells during chick gastrulation by regulating $\mathrm{N}$-cadherin expression. Development 135: 3521-3530.

Yeung T, Georges PC, Flanagan LA, Marg B, Ortiz M, Funaki M, Zahir N, Ming W, Weaver V, Janmey PA (2005) Effects of substrate stiffness on cell morphology, cytoskeletal structure, and adhesion. Cell Motil Cytoskeleton 60: 24-34.

Supplementary Table 1

\begin{tabular}{|c|c|c|c|c|c|}
\hline Gene name & $\begin{array}{l}\text { GenBank } \\
\text { Accession }\end{array}$ & Sequence & $\begin{array}{l}\text { Amplicon } \\
\text { length }\end{array}$ & $\begin{array}{l}\text { Cycling } \\
\text { conditions }\end{array}$ & $\begin{array}{l}\text { Starting } \\
\text { conc } \\
\text { RNA } \\
(\mathrm{ng} / \mu \mathrm{L})\end{array}$ \\
\hline Runx2 & NM_009820 & $\begin{array}{l}\text { CCAACCGAGTCATTTAAGGCT } \\
\text { GCTCACGTCGCTCATCTTG }\end{array}$ & 207 & $\begin{array}{l}95^{\circ} \mathrm{C} 10 \mathrm{~s} \\
56^{\circ} \mathrm{C} 15 \mathrm{~s} \\
72^{\circ} \mathrm{C} 15 \mathrm{~s}\end{array}$ & 4 \\
\hline Eomes/Tbr2 & NM_010136 & $\begin{array}{l}\text { GGCCCCTATGGCTCAAATTCC } \\
\text { CCTGCCCTGTTTGGTGATG }\end{array}$ & 62 & $\begin{array}{l}95^{\circ} \mathrm{C} 10 \mathrm{~s} \\
56^{\circ} \mathrm{C} 15 \mathrm{~s} \\
72^{\circ} \mathrm{C} 15 \mathrm{~s}\end{array}$ & 4 \\
\hline Spp1 & NM_009263 & $\begin{array}{l}\text { AGCAAGAAACTCTTCCAAGCAA } \\
\text { GTGAGATTCGTCAGATTCATCCG }\end{array}$ & 134 & $\begin{array}{l}95^{\circ} \mathrm{C} 10 \mathrm{~s} \\
56^{\circ} \mathrm{C} 15 \mathrm{~s} \\
72^{\circ} \mathrm{C} 15 \mathrm{~s}\end{array}$ & 4 \\
\hline Nanog & NM_028016 & $\begin{array}{l}\text { TTGCTTACAAGGGTCTGCTACT } \\
\text { ACTGGTAGAAGAATCAGGGCT }\end{array}$ & 106 & $\begin{array}{l}95^{\circ} \mathrm{C} 10 \mathrm{~s} \\
56^{\circ} \mathrm{C} 15 \mathrm{~s} \\
72^{\circ} \mathrm{C} 15 \mathrm{~s}\end{array}$ & 4 \\
\hline Mixl1 & NM_013729 & $\begin{array}{l}\text { ACGCAGTGCTTTCCAAACC } \\
\text { CCCGCAAGTGGATGTCTGG }\end{array}$ & 196 & $\begin{array}{l}95^{\circ} \mathrm{C} 10 \mathrm{~s} \\
56^{\circ} \mathrm{C} 15 \mathrm{~s} \\
72^{\circ} \mathrm{C} 15 \mathrm{~s}\end{array}$ & 4 \\
\hline Twist1 & NM_011658 & $\begin{array}{l}\text { GGACAAGCTGAGCAAGATTCA } \\
\text { CGGAGAAGGCGTAGCTGAG }\end{array}$ & 146 & $\begin{array}{l}95^{\circ} \mathrm{C} 10 \mathrm{~s} \\
56^{\circ} \mathrm{C} 15 \mathrm{~s} \\
72^{\circ} \mathrm{C} 15 \mathrm{~s}\end{array}$ & 4 \\
\hline Brachyury & NM_009309 & $\begin{array}{l}\text { GCTTCAAGGAGCTAACTAACGAG } \\
\text { CCAGCAAGAAAGAGTACATGGC }\end{array}$ & 117 & $\begin{array}{l}95^{\circ} \mathrm{C} 10 \mathrm{~s} \\
56^{\circ} \mathrm{C} 15 \mathrm{~s} \\
72^{\circ} \mathrm{C} 15 \mathrm{~s}\end{array}$ & 4 \\
\hline Fgf5 & NM_010203 & $\begin{array}{l}\text { TGTGTCTCAGGGGATTGTAGG } \\
\text { AGCTGTTTTCTTGGAATCTCTCC }\end{array}$ & 137 & $\begin{array}{l}95^{\circ} \mathrm{C} 10 \mathrm{~s} \\
56^{\circ} \mathrm{C} 15 \mathrm{~s} \\
72^{\circ} \mathrm{C} 15 \mathrm{~s}\end{array}$ & 4 \\
\hline Foxa2 & NM_010446 & $\begin{array}{l}\text { CCCTACGCCAACATGAACTCG } \\
\text { GTTCTGCCGGTAGAAAGGGA }\end{array}$ & 222 & $\begin{array}{l}95^{\circ} \mathrm{C} 10 \mathrm{~s} \\
56^{\circ} \mathrm{C} 15 \mathrm{~s} \\
72^{\circ} \mathrm{C} 15 \mathrm{~s}\end{array}$ & 4 \\
\hline Sox1 & NM_009233 & $\begin{array}{l}\text { AAGGAACACCCGGATTACAAGT } \\
\text { GTTAGCCCAGCCGTTGACAT }\end{array}$ & 231 & $\begin{array}{l}95^{\circ} \mathrm{C} 10 \mathrm{~s} \\
56^{\circ} \mathrm{C} 15 \mathrm{~s} \\
72^{\circ} \mathrm{C} 15 \mathrm{~s}\end{array}$ & 4 \\
\hline Gata6 & NM_010258 & $\begin{array}{l}\text { TTGCTCCGGTAACAGCAGTG } \\
\text { GTGGTCGCTTGTGTAGAAGGA }\end{array}$ & 105 & $\begin{array}{l}95^{\circ} \mathrm{C} 10 \mathrm{~s} \\
56^{\circ} \mathrm{C} 15 \mathrm{~s} \\
72^{\circ} \mathrm{C} 15 \mathrm{~s}\end{array}$ & 4 \\
\hline Cdh1 & NM_009864 & $\begin{array}{l}\text { CAGGTCTCCTCATGGCTTTGC } \\
\text { CTTCCGAAAAGAAGGCTGTCC }\end{array}$ & 175 & $\begin{array}{l}95^{\circ} \mathrm{C} 10 \mathrm{~s} \\
56^{\circ} \mathrm{C} 15 \mathrm{~s} \\
72^{\circ} \mathrm{C} 15 \mathrm{~s}\end{array}$ & 4 \\
\hline Cdh2 & NM_007664 & $\begin{array}{l}\text { AGCGCAGTCTTACCGAAGG } \\
\text { TCGCTGCTTTCATACTGAACTTT }\end{array}$ & 101 & $\begin{array}{l}95^{\circ} \mathrm{C} 10 \mathrm{~s} \\
56^{\circ} \mathrm{C} 15 \mathrm{~s} \\
72^{\circ} \mathrm{C} 15 \mathrm{~s}\end{array}$ & 4 \\
\hline Gapdh & NM_008084 & $\begin{array}{l}\text { AGGTCGGTGTGAACGGATTTG } \\
\text { TGTAGACCATGTAGTTGAGGTCA }\end{array}$ & 123 & $\begin{array}{l}95^{\circ} \mathrm{C} 10 \mathrm{~s} \\
56^{\circ} \mathrm{C} 15 \mathrm{~s} \\
72^{\circ} \mathrm{C} 15 \mathrm{~s}\end{array}$ & 0.04 \\
\hline
\end{tabular}




\section{Supplementary methods}

\section{Collagen Quantification}

Collagen attachment to PDMS surfaces was confirmed with an assay based on the binding of biotinylated fibronectin to Type I Collagen, as has been previously described (Gaudet et al., 2003). Briefly, fibronectin (Sigma) was biotinylated with an EZ-Link ${ }^{\circledR}$ Sulfo-NHSBiotinylation Kit (Pierce Biotechnology, Rockford, IL, USA) according to the manufacturer's instructions. PDMS surfaces and TCP coated with Type I Collagen as described in the 'Materials Synthesis' section were rinsed 6 times with distilled water, treated for 30 minutes with a blocking buffer of $2 \%(\mathrm{w} / \mathrm{v})$ BSA (Sigma) and $0.05 \%(\mathrm{v} / \mathrm{v})$ Tween20 (GE Healthcare formerly Amersham Biosciences) in PBS. Biotinylated fibronectin was then added to the surfaces and allowed to attach for 1 hour at $37{ }^{\circ} \mathrm{C}$. Substrates were then rinsed three times with rinsing buffer consisting of $0.1 \%(\mathrm{v} / \mathrm{v})$ Tween-20 in PBS. They were then incubated for an additional 30 minutes at $37^{\circ} \mathrm{C}$ with 50 $\mathrm{ng} / \mathrm{mL}$ horseradish peroxidise-streptavadin (Pierce Biotechnology) in blocking buffer. Substrates were rinsed 3 times and the substrate 3,3',5,5' -tetramethylbenzidine (TMB) (Pierce Biotechnology) was added and allowed to develop for 10 minutes at room temperature. The reaction was stopped with an equal volume of $2 \mathrm{M} \mathrm{H}_{2} \mathrm{SO}_{4}$ and absorbance values were measured on a colorimetric plate reader at $450 \mathrm{~nm}$.

\section{ICP analysis of cell culture medium}

Samples of cell culture medium were collected after 4 days from cell seeding and the presence of $\mathrm{Si}$ atoms from the substrate in the media was measured by inductively coupled plasma (ICP) spectroscopy (iCAP 6300, Thermo Fisher Scientific, Loughborough, UK).

\section{Reference}

Gaudet C, Marganski WA, Kim S, Brown CT, Gunderia V, Dembo M, Wong JY (2003) Influence of type I collagen surface density on fibroblast spreading, motility, and contractility. Biophys J 85: 3329-3335.
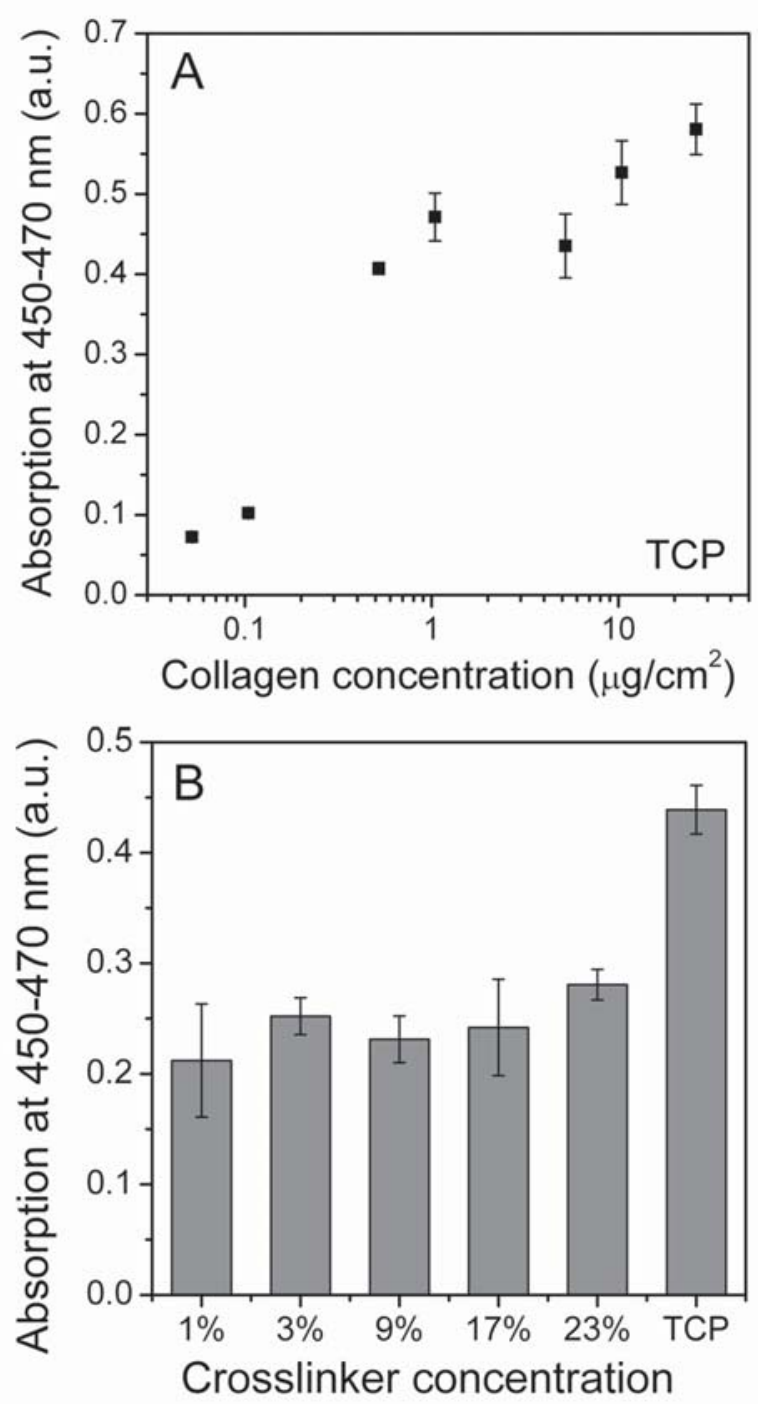

Supplementary Figure 1

\section{Discussion with Reviewers}

J Hayes: Have the authors attempted to compare nonstimulated (i.e. without osteogenic supplements) embryonic stem cells to see if a stiffness specific differentiation response exists?

Authors: We have not attempted this experiment. On all substrates osteogenic supplements were added, therefore we would argue there is a stiffness-specific stimulation of osteogenesis. On stiff tissue culture plastic, we do not see bone nodule formation in the absence of osteogenic supplements. Therefore we would not expect to see bone nodule formation on PDMS substrates in the absence of supplements.
J Hayes: Did the authors observe any substrate stiffness changes in the expression of the housekeeping gene? Authors: To answer this pertinent question we have reanalysed our data from 7 separate time course experiments. We averaged the fluorescence intensity values at which the SYBR green signal crossed a given threshold (the $\mathrm{Ct}$ value) for each substrate and for EBs. We found $\mathrm{Ct}$ values of $18.1 \pm 0.8$ for PDMS1, $18.3 \pm 0.5$ for PDMS3, $18.9 \pm 0.8$ for PDMS9, $18.3 \pm 0.6$ for PDMS17, $18.2 \pm 0.7$ for PDMS 23; $18.4 \pm 0.6$ for TCP; and $18.5 \pm 0.6$ for EBs. No group was statistically significant from any other $(p>0.2)$. We also analysed a possible time-dependence of Gapdh expression by 
examining Gapdh expression at each time point. We found $\mathrm{Ct}$ values of $19.9 \pm 1.3$ at day 0 (ESCs), $18.3 \pm 0.8$ at day $4,18.5 \pm 0.9$ at day $6,18.3 \pm 0.8$ at day 8 and $19.1 \pm 0.9$ at day 10 . The $\mathrm{Ct}$ value was significantly higher in undifferentiated ESCs (day 0) than at any other timepoint $(p<0.05)$ but there were no significant differences between other timepoints. Given the efficiency of the Gapdh primer pair we used (1.81), on average Gapdh expression is reduced by a factor of 2-3 in differentiated compared to undifferentiated ESCs. While equal masses of RNA were added to each PCR reaction tube, one should note that the mass of RNA in each reaction was measured by its absorbance, Values obtained using this technique may be affected by the presence of protein which could interfere with measurement -as undifferentiated ESCs contain less protein than differentiating ESCs this may account for some of the discrepancy.

J Hayes: The authors state that they suspect that the elastic moduli of the substrates used in their study are higher than those in the early embryo. Do they believe therefore, that the results presented are merely an outcome of an in vitro 'artefact'? Obviously the data are still of great interest. I am just wondering if the authors can assign specific biological relevance to their data, given that bone differentiation - according to the authors - appears to be influenced at much lower magnitudes of tissue stiffness. Authors: It is difficult to answer this question concisely. The in vitro environment can never hope to replicate in vivo complexities, but it does allow us to reduce the number of variables we encounter in an experiment and to pin firmer conclusions to given observations. Strictly speaking, any in vitro experiment is artificial. We chose to take one variable and test whether it affects ESC differentiation. Of course, the embryo is not a static system and much more complex. But our results show that the substrates in our manuscript still do have significant effects on differentiation, for reasons we suggest in the discussion.

J Hayes: The author's show that many of the genes studied were expressed at much higher levels in the embyroid bodies and attribute this observation to differences between $2 \mathrm{D}$ and $3 \mathrm{D}$ culture, which of course is very plausible. I am wondering however if, by chance, the authors measured the Young's modulus of the EBs (if this is even possible?) and if so how did this compare to the liver and calvarium samples and did the measurements correlate to their observations?

Authors: Unfortunately we did not measure EB stiffness. It would be interesting in future studies to measure the stiffness of both EBs and early embryos. We believe this to be experimentally feasible.

G Reilly: Some of the authors recently published a very interesting paper in Nature Materials showing that the mineralisation achieved in ESC culture is not of the same structure and quality as that created by adult stem cells (MSCs) or fully differentiated osteoblasts. Do they think this also applies to the mineralisation seen in these cultures? Would they expect substrate stiffness to affect the quality/ structure of mineralised nodules

Authors: In answer to the first question - yes. These experiments were conducted in parallel with those reported in the Nature Materials paper. We think that the quality of the mineralised nodules formed from ESCs in this study is comparable to those in the Nature Materials paper. In answer to the second question - we don't know, as we haven't tested it. There is more mineralisation on harder substrates than soft ones but we don't know whether it is qualitatively different. This is very interesting and the subject of ongoing research in our group. 